\title{
Evaluation of Various Training Aspects of Agriclinics and Agribusiness Centres (ACABC's) Scheme in Rajasthan, India
}

\author{
Shoji Lal Bairwa ${ }^{1 *}$, Saket Kushwaha ${ }^{2}$, Chandra Sen $^{2}$, Rakesh Singh ${ }^{2}$ and D. C. Rai ${ }^{3}$ \\ ${ }^{1}$ Department of Agricultural Economics, DKAC, Kishanganj - 855107, India \\ ${ }^{2}$ Department of Agricultural Economics, Banaras Hindu University, Varanasi - 221005, India \\ ${ }^{3}$ Department of Animal Husbandry and Dairy, Banaras Hindu University, \\ Varanasi - 221005, India \\ *Corresponding author
}

\section{A B S T R A C T}

\section{Keywords}

ACABCs scheme,

Information

sources, NTIs,

Training

preferences,

Trainees seriousness and Rajasthan state.

Article Info

Accepted:

12 April 2017

Available Online:

10 May 2017
A subsidy based credit linked training programme "agriclinics and agribusiness centres scheme" was launched by government of India on 9th April, 2002 to strengthen the transfer of technology, extension services and also provide self-employment opportunities to technically trained agricultural graduates. The present study was conducted on the basis of primary data collected through field survey from 150 sample agrigraduates in Rajasthan state during 2011 to 2015 . The 50 trained agrigraduates were randomly selected as sample agripreneurs from each NTI in three batches i.e. recently batch 2013, middle batch 2007 and beginning batch 2002-03. Primary data were collected through questionnaires which were pretested with a sample of 25 agrigraduates in the same study area but other than the non-sample agrigraduates. Pre-testing of instruments was done to know whether the contents and forms of the questionnaire were valid, reliable and easily understandable by the respondents or not. The statistics such as frequencies, scores, percentages and ranking were used to analyse the various aspects of the scheme. Present study examines the whole scheme from various angles (aspects) such as sources of information, place of training, year of completion, factors motivated to join training programme, facilities provided by the training institutes, study material, courses offered in training, classes conducted by the training institutes, seriousness of candidate about training and final feedback of the trainees about training programme. In findings, it was found that friends and newspaper were the major source of information about the ACABCs training programme as it was responded by 76.00 per cent and 13.34 per cent of total 150 agripreneurs while MPUAT, Udaipur was found to be very good training institute with the mean scores of 56.80 , followed by JSBFM, Jaipur and RICEM Udaipur were found to be good with the mean scores of 51.10 and 50.70 respectively.

\section{Introduction}

Government of India constituted a steering committee on agriculture and allied sectors under the chairmanship of Prof. M.S. Swaminathan.
The committee suggested creation of agriclinics and agribusiness centres managed by agri-graduates so as to provide consultancy services to the farming community in rural 
areas (Karjagi, 2006). Subsequently, the union finance minister had announced for setting-up agriclinics and agribusiness centre with the support of National Bank for Agriculture and Rural Development in February, 2001 during the budget. Thus, The scheme of 'Agriclinics and Agri business Centres' was launched on 9th April, 2002 to strengthen the transfer of technology and extension services and also provide selfemployment opportunities to technically trained persons (Evaluation report, 2010; Ahmed et al., 2011 and Bairwa et al., 2015). The scheme is open to agriculture graduates / graduates in the subject allied to agriculture like horticulture, animal husbandry, dairy, veterinary, poultry farming, fish culture and forestry (MANAGE, 2013 and Bairwa et al., 2014). The programme was designed to develop opportunities for private extension to lower the burden on public funding, to offer a wider range of advice in specialist areas and to develop challenging job for agricultural graduates (Kanwat et al., 2011). The present study carried out to evaluate the various training aspects of the agriclinics and agribusiness centre scheme and these training aspects includes information about the training programmes, place of training, year of completion, factors motivated to join training programme, facilities provided by the training institutes, study material, courses offered in training, classes conducted by the training institutes, seriousness of candidate about training and final feedback of the trainees about training programme.

\section{Materials and Methods}

The present study was conducted in rajasthan state from the year 2011 to 2015. Rajasthan state comprises 33 districts, out of these, 5 district were selected purposively viz. Jaipur, Udaipur, Alwar, Tonk, and Sri Ganganagar because these districts have maximum number of trained candidates and reported good number of success stories and made good progress of loans. The study is based on the both primary and secondary which were collected through different sampling procedures from the trainees, training institutes, nodal agency and successful trained candidates. The fifty (50) trained candidates/agrigraduates were randomly selected as sample agri graduates from each NTI in three batches i.e. recently batch2013, middle batch 2007 and beginning batch 200203. Primary data were collected from 150 trained agrigraduates through questionnaires which was pretested with a sample of 25 agrigraduates in the same study area but other than the non-sample agrigraduates. Pre-testing of instruments was done to know whether the contents and forms of the questionnaire were valid, reliable and easily understandable by the respondents or not. The statistics such as frequencies, scores, percentages and ranking were used to analyse the various aspects of the scheme. To know the final feedback of the trainees about the training institutions, the data were collected from 50 sample trainees from each institution (150 trainees for Rajasthan state) on training components like faculty, theory, study visits, interaction, audio visual aids, video conferencing and infrastructure components like, lodging, boarding, transport and others. The data so obtained was subjected to scoring; the percentage weights are assigned depending upon the preferences given for each component by the trainees about the training programme.

\section{Results and Discussion}

\section{Sources of information about $\mathrm{AC}$ and} ABCs training programme

Table 1 shows that the information about the ACABCs training programme from friends was found to be a major source of information as it was responded by $114 \quad(76.00 \%)$ agripreneurs followed by newspaper, which was responded by 20 (13.34\%) agripreneurs. 
Electronic media and university notice board were the additional sources of information, which have given the information to 6 agripreneurs and 10 agripreneurs accounted for 4 per cent and 6.6 per cent respectively. It is surprising that in the era of information and communication technology (ICTs), very less number of sample agripreneurs obtained the information from electronic media, newspapers. The reasons for this may be the non-availability and lack of experience of IT based services like internet, and less publicity in mass media. More convenient and clarification about the training programme from friends who undergone training was found to be the main source of information due to the availability of the mobile phone numbers and their intimate relationships. These results are in conformity with the results obtained by Rao and Rupkumar (2005). They found that 63 and 74 per cent of the information about training programme was disseminated through friends and newspapers respectively. Karjagi (2006) also reported that friends and other (university notice board, training institutes) were the major source of information $(74.81 \%$ and $45.19 \%)$ followed by electronic media (20\%) in south India.

\section{Facilities used by agripreneurs at the Nodal Training Institutes}

The apex institute MANAGE set the guidelines for nodal training institute (NTIs) to provide free lodging, boarding, classroom, library, fields for practical, computer with internet, newspaper and other facilities to the trainees under ACABCs. In this context, facilities provided by training institutes were evaluated and results are presented in table 2 . Table shows that all training institutes have been provide minimum basic facilities like lodging, boarding, classroom and library. Besides these modern facilities like computer with internet, machinery, field for practical, newspapers, phone and fax etc. were made available to some extent by all the institutes. Even some of the institutes like MPUAT, Udaipur have made the facilities for sports and recreational but the per cent of usage of these facilities was found to be less due to the busy schedule of classes in training and their other personal works.

It revealed from table 2 that all the trainees under the scheme of ACABCs in Rajasthan have utilized the free facilities of lodging, boarding and class room. The library and computer with internet facilities were enjoyed by 23.36 per cent and 50 per cent respondents, respectively. However, field for practical, machinery and sports facilities utilized by 40.00 per cent, 42.00 per cent and 22.67 per cent respondents respectively. Similarly, the facilities like phone/fax, and newspapers were utilized by 51.34 per cent, and 94.67 per cent of the trainees, respectively. These results are similar as obtained by Rao and Rupkumar (2005) and Karjagi (2006) in their research study.

\section{Training preferences of agrigraduates under the scheme of $\mathrm{ACABCs}$}

To assess the training needs of the trainees, the data on several training areas such as agribusiness management, information technology, small business management, general marketing management, agri marketing management, and financial management were collected from the sample agripreneurs. The data collected were scored and ranked on the basis of preference and presented in table 3 .

The table 3 shows that the ranking of different areas in which the trainees needs training under the scheme of ACABCs. The information technology (IT) has got top priority by the sample agripreneurs as the major area of training. Information technology includes various components such as agricultural MIS, commercial 
dissemination of information, scope and local application of e-commerce, up linking IT kiosks, MS-Office and Internet, Information Kiosks, concepts and uses, agricultural portals, IT application and their advantages, Role of IT in changing business with special reference to small business, linking procedure to IT led applications and brief introduction to information technology.

General marketing management was the second most important area which includes rural marketing issues, advertising management and its impact, marketing of services, sales operations and management, sales promotion, retail marketing, pricing and price policies, distribution management, brands, product features and packaging, marketing channels and introduction to marketing, concepts and general principles. This clearly indicates that they were lack of skills in information technology and marketing management before training programme. These aspects of marketing management are most important in the today's business environment. Hence, the trainees might have given the second preference to this area for training. Karjagi (2006) was also reported that information technology (IT) and general marketing management are two most important areas of training under $\mathrm{AC}$ and $\mathrm{ABCs}$ scheme in south India. The third most important area of training was financial management which includes skills like preparing projects for bank appraisals, project analysis techniques, projects appraisals and reports, capital expenditure decisions, process of capital, capitalizing and reinvesting, assessing projects for profit abilities with respect to farmers and general principles and practices financial management. Fourth most important area was agri marketing management which includes quality issues, standardization, grading and packaging, crop insurance, procurement management, franchise issues, problems and prospects, pre-harvest planning services, marketing environment of seed fertilizers, pesticides and other farm machineries and special features of agricultural input marketing. Although, the areas of financial management and agri marketing management were learnt during their graduation but still they want to fresh up, because without these aspects they cannot run business. The management of small businesses and agribusiness management were got fifth and sixth rank among all areas of training under scheme of ACABCs respectively. The management of small business includes aspects such as operating franchise, importance of franchising, some pit falls in franchising, identifying, developing and diversification of small business, marketing and sales service, managing small business, small business networking and components, and characteristics of small business as these trainees need these things in managing their small business.

The training needs in the area of agribusiness management like agribusiness development analysis and opportunities, forms of agribusiness organizations, their advantages and disadvantages, scope of agribusiness, status, present role and future prospects, and agribusiness concepts, nature and scope. Most of the trainees were fresh graduates and few were experienced. Hence, they were interested in starting their business in small scale in the beginning so they demand for training in managing small business and its components. The training need in the area of agribusiness management and its components was found to be least important due to updated knowledge about current agribusiness scenario through mass media, newspapers, magazines, periodicals and other means.. 
Table.1 Sources of information about ACABC training programme

\begin{tabular}{|l|l|c|c|}
\hline S. No. & \multicolumn{1}{|c|}{ Information sources } & No. of respondents & Percentage \\
\hline 1 & Newspaper & 20 & 13.34 \\
\hline 2 & Friends & 114 & 76.00 \\
\hline 3 & Electronic media & 6 & 4.00 \\
\hline 4 & University Notice Board & 10 & 6.60 \\
\hline
\end{tabular}

Source: Field study, 2013

Table.2 Facilities used by agripreneurs at the nodal training institutes

\begin{tabular}{|c|c|c|c|c|c|c|c|c|c|}
\hline \multirow[t]{3}{*}{ S.No. } & \multirow[t]{3}{*}{ Facilities } & \multicolumn{6}{|c|}{$\mathrm{N}=\mathbf{5 0}$ for individual training institute } & \multirow{2}{*}{\multicolumn{2}{|c|}{ Rajasthan }} \\
\hline & & \multicolumn{2}{|c|}{ JSBFM, Jaipur } & \multicolumn{2}{|c|}{ RICEM, Jaipur } & \multicolumn{2}{|c|}{ MPUAT, Udaipur } & & \\
\hline & & No. & $\%$ & No. & $\%$ & No. & $\%$ & No. & $\%$ \\
\hline 1. & Lodging & 50 & 100.00 & 50 & 100.00 & 50 & 100.00 & 150 & 100.00 \\
\hline 2. & Boarding & 50 & 100.00 & 50 & 100.00 & 50 & 100.00 & 150 & 100.00 \\
\hline 3. & Classroom & 50 & 100.00 & 50 & 100.00 & 50 & 100.00 & 150 & 100.00 \\
\hline 4. & Library & 00 & 00.00 & 10 & 20.00 & 25 & 50.00 & 35 & 23.36 \\
\hline 5. & Computer & 20 & 40.00 & 25 & 50.00 & 30 & 60.00 & 75 & 50.00 \\
\hline 6. & $\begin{array}{l}\text { Practical } \\
\text { Field }\end{array}$ & 08 & 16.00 & 12 & 24.00 & 40 & 80.00 & 60 & 40.00 \\
\hline 7. & Machinery & 08 & 16.00 & 15 & 30.00 & 40 & 80.00 & 63 & 42.00 \\
\hline 8. & Sports & 00 & 00.00 & 00 & 00 & 34 & 68.00 & 34 & 22.67 \\
\hline 9. & Phone, Fax & 21 & 42.00 & 24 & 48.00 & 32 & 64.00 & 77 & 51.34 \\
\hline 10 & Newspaper & 45 & 90.00 & 47 & 94.00 & 50 & 100.00 & 142 & 94.67 \\
\hline
\end{tabular}

Source: Field study, 2013 
Table.3 Training Preferences of agri graduates under the scheme of AC and ABCs

\begin{tabular}{|l|l|c|c|}
\hline S.No. & \multicolumn{1}{|c|}{ Training Areas } & Total Score & Rank \\
\hline 1. & Agribusiness management & 219 & VI \\
\hline 2. & Managing small business & 264 & V \\
\hline 3. & General marketing management & 348 & II \\
\hline 4. & Agri marketing management & 270 & IV \\
\hline 5. & Financial management & 309 & III \\
\hline 6. & Information technology (IT) & 390 & I \\
\hline
\end{tabular}

Source: Field study, 2013

Table.4 Seriousness of trainees about the $\mathrm{AC}$ and $\mathrm{ABC}$ training programme

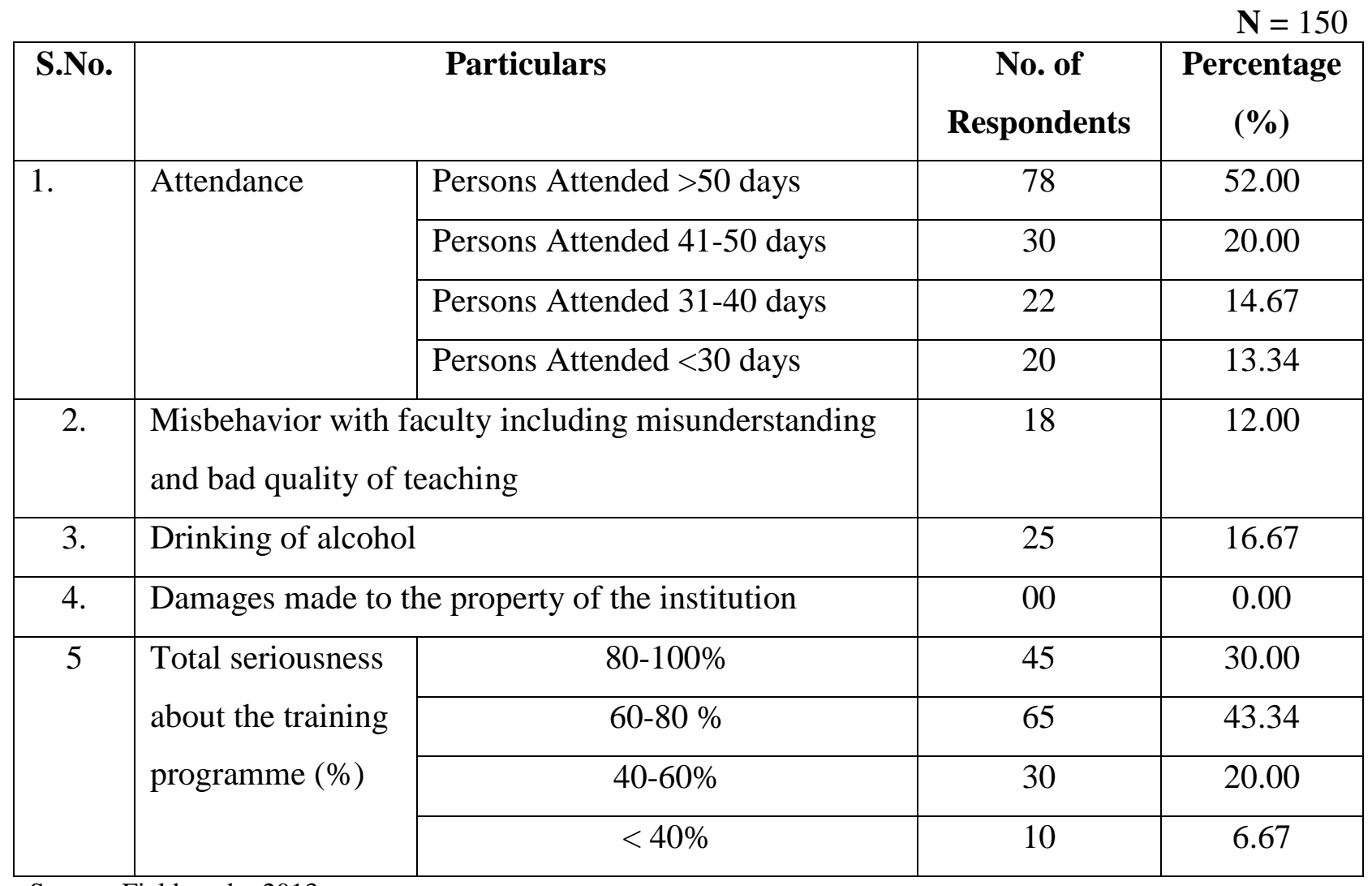

Source: Field study, 2013 
Table.5 Final feedback of the trainees about the training institutions

\begin{tabular}{|c|c|c|c|c|c|c|c|c|c|}
\hline \multirow[t]{2}{*}{ S.No. } & \multirow[t]{2}{*}{ Components } & \multicolumn{2}{|c|}{ JSBFM, Jaipur } & \multicolumn{2}{|c|}{ RICEM, Jaipur } & \multicolumn{2}{|c|}{ MPUAT, Udaipur } & \multicolumn{2}{|c|}{ Rajasthan } \\
\hline & & Score & $\%$ weight & Score & $\%$ weight & Score & $\%$ weight & Score & $\%$ weight \\
\hline \multicolumn{10}{|c|}{ A. Training Components } \\
\hline 1. & Faculty & 65 & 65.00 & 67 & 67.00 & 74 & 74.00 & 206 & 68.67 \\
\hline 2. & Theory sessions & 56 & 56.00 & 60 & 60.00 & 65 & 65.00 & 181 & 60.34 \\
\hline 3. & Study visits & 54 & 54.00 & 56 & 56.00 & 60 & 60.00 & 170 & 56.67 \\
\hline 4. & Interactions & 55 & 55.00 & 54 & 54.00 & 58 & 58.00 & 167 & 55.67 \\
\hline 5. & Audio-video aids & 42 & 42.00 & 40 & 40.00 & 45 & 45.00 & 127 & 42.34 \\
\hline 6. & Video conferencing & 14 & 14.00 & 0 & 0.00 & 22 & 22.00 & 36 & 12.00 \\
\hline \multicolumn{10}{|c|}{ B. Infrastructural Components } \\
\hline 1. & Lodging & 83 & 83.00 & 85 & 85.00 & 92 & 92.00 & 260 & 86.67 \\
\hline 2. & Boarding & 70 & 70.00 & 75 & 75.00 & 80 & 80.00 & 230 & 76.67 \\
\hline 3. & Transportation & 45 & 45.00 & 50 & 50.00 & 49 & 49.00 & 144 & 48.00 \\
\hline 4. & Others & 27 & 27.00 & 20 & 20.00 & 23 & 23.00 & 70 & 23.34 \\
\hline \multicolumn{10}{|c|}{ C. Overall Impression/ Feedback } \\
\hline & Mean Scores & $(51.10)$ & Good & $(50.70)$ & Good & $(56.80)$ & V. Good & $(159.10)$ & Good \\
\hline
\end{tabular}

Source: Field study, 2013

Note: Figure in the parenthesis indicates mean of the mean scores

Maximum score $=100$ for individual training institutes

Maximum score $=300$ for Rajasthan as a whole 
These results are quite similar as obtained by Karjagi (2006) and Karjagi et al., (2007) in their study in south India

\section{Seriousness of trainees about the training programme}

To assess the seriousness of the trainees about the training programme under the scheme of ACABCs, the data on some of the factors like attendance, misbehaviour with faculty, drinking alcohol and damages made to the property of the institution were considered. The total seriousness about the training programme was calculated with the help of weighted averages and percentages and the results are presented in table 4. Table 4 reveals that 52 per cent trainees (78) have attended more than 50 days training, 20 per cent trainees (30) have attended 41 - 50 days training, 14.67 per cent trainees (22) have attended $31-40$ days training and 13.34 per cent trainees (20) have attended less than 30 days training. This may be because of their interest and need of the training in undertaking the projects. Misbehaviour with the faculty, drinking alcohol and damages made to the property of institution were of 12 per cent, 16.67 per cent and nil, respectively. The misbehaviour was due to their dissatisfaction of lectures during the training hours. Damage made to the property of institution were nil due to the responsibility and matured mind of trainees. Out of 150 respondents, 45 respondents are $80-100$ per cent serious, 65 respondents are $66-80$ per cent, 30 respondents are $40-60$ per cent serious and only 10 respondents are less 40 per cent serious about the training programme. Karjagi (2006) and Karjagi et al., (2007) were also reported the similar results in their study in south India.

\section{Final feedback of trainees about the training and nodal training institutions}

Table 5 shows that all the training institutes were given more than 60 per cent weightage for faculty and 50 to 60 per cent weight for theory while in Rajasthan as a whole 68.67 per cent and 60.34 per cent weights were given for faculty and theory respectively. All the training institutes and Rajasthan as a whole was given more than 50 per cent weights for study visits and interactions but in case of audio visual aids all the training institutes including Rajasthan as a whole were given less than 50 per cent weights. However, JSBFM, Jaipur and MPUAT, Udaipur were the only two institution which were given the weight of 14 per cent and 22 per cent for video conference. In case of infrastructure components, lodging and boarding were assigned by more than 80 per cent weights for all the institutes and Rajasthan as a whole, while all institutes were give less than 50 per cent weightage for transportation. In case of other components, all the institutes and Rajasthan as a whole were given less than 30 per cent weightage. In case of overall feedback of the trainees, MPUAT, Udaipur was found to be very good with the mean scores of 56.80 because of their high performance in both training and infrastructure components followed by JSBFM, Jaipur and RICEM Udaipur were found to be good with the mean scores of 51.10 and 50.70. The overall feedback about the training institutions in Rajasthan was found to be good with the mean score of 159.10. Similar study was conducted in Maharashtra by Rao and Rupkumar (2005) and in South India by Karjagi (2006) and they found that individual training components and video conferencing along with transportation were rated as quite satisfactory.

It has been concluded that Agriclinics and agribusiness centre scheme is very important for rural and urban youths because it provide employment opportunity with the specialized training, credit facility, subsidy and handholding support for the establishment of their agribusiness/agriventure. Present study examines the whole scheme from various 
angles (aspects) and found that the friends and newspaper were the major source to provide information to respondents about the $\mathrm{AC}$ ABCs training programme as it was responded by $114(76.00 \%)$ and 20 (13.34\%) agripreneurs among 150 agripreneurs. The study result shows that all training institutes have been provide minimum basic facilities like lodging, boarding, classroom and library at free of cost. The information technology (IT) and general marketing management has got top priority by the sample agripreneurs as the major area of training. The study reveals that 52 per cent trainees (78) have attended more than 50 days training, 20 per cent trainees (30) have attended 41 - 50 days training, 14.67 per cent trainees (22) have attended 31 - 40 days training and 13.34 per cent trainees (20) have attended less than 30 days training.

Present study also shows that all the training institutes were given more than 60 per cent weightage for faculty and 50 to 60 per cent weight for theory while in Rajasthan as a whole 68.67 per cent and 60.34 per cent weights were given for faculty and theory respectively.

All the training institutes and Rajasthan as a whole was given more than 50 per cent weights for study visits and interactions but in case of audio visual aids all the training institutes including Rajasthan as a whole were given less than 50 per cent weights. In case of overall feedback of the trainees, MPUAT, Udaipur was found to be very good with the mean scores of 56.80 because of their high performance in both training and infrastructure components followed by JSBFM, Jaipur and RICEM Udaipur were found to be good with the mean scores of 51.10 and 50.70. The overall feedback about the training institutions in Rajasthan was found to be good with the mean score of 159.10.

\section{Acknowledgement}

First author is highly thankful to the Dr. Kerobim Lakra and all sample agripreneurs for their kind support and active participation in field survey during research study. I obey my sincere gratitude to university grants commission (UGC) New Delhi for financial support as fellowship during my $\mathrm{Ph}$. D. programme.

\section{References}

Ahmed, T., Hasan, S. and Haneef, R. 2011. Entrepreneurial Characteristics of the Agripreneurs under the Scheme of Agriclinics \& Agribusiness Centres, $J$. Community Mobilization and Sustainable Develop., 6(2): 145-149.

Bairwa, Shoji Lal, Kushwaha, Saket and Sen, Chandra. 2015. Problems faced by agripreneurs in starting and operating agriventures under ACABCS scheme in Rajasthan state, Int. J. Agri. Sci. Res., 5(2): 203-208.

Bairwa, Shoji Lal, Kushwaha, Saket, Meena, Lokesh Kumar and Lakra, Kerobim. 2014. Present status of agriclinics and agribusiness centres scheme in India: An Analysis, Int. J. Scientific Res. Manage., 2(9): 1431-1440.

Evaluation Report. 2010. Evaluation Study of Agriclinics and agribusiness centre Scheme by Global Agrisystem Private Limited, New Delhi.

Kanwat, Manish, Chargotra, Meenakshi, Kumar, P.S. and Mishra, B.P. 2011. Attitude of the agricultural graduate towards agriclinic and agribusiness centres in Arunachal Pradesh, Indian Res. J. Ext. Edu., 11(1): 117-119.

Karjagi, R. 2006. Performance of agriclinics and agribusiness centres scheme in south India, Ph.D. Thesis, University of Agricultural Sciences, Dharwad, Bangalore.

Karjagi, R., Khan, H.S.S. and Vijaykumar, H.S. 2007. Factors affecting participation in 
Agriclinic and agribusiness centres programme in South India, Karnataka J. Agri. Sci., 20(4): 873-875.

Manage. 2013. Database available at Agriclinics and Agribusiness Centres Cell, MANAGE, Hyderabad, retrieved from http://www.agriclinics.net.
Rao, M.V. and Rupkumar, K. 2005. Concurrent evaluation of agriclinics and agribusiness centers scheme (AAG) in Maharashtra, A report submitted to National Institute of Agricultural Extension Management. pp. 57-124.

\section{How to cite this article:}

Shoji Lal Bairwa, Saket Kushwaha, Chandra Sen, Rakesh Singh and Rai, D.C. 2017. Evaluation of Various Training Aspects of Agriclinics and Agribusiness Centres (ACABC's) Scheme in Rajasthan. Int.J.Curr.Microbiol.App.Sci. 6(5): 1363-1372. doi: https://doi.org/10.20546/ijcmas.2017.605.147 